DOI: $10.22616 /$ foodbalt.2017.042

\title{
QUALITY AND FOOD SAFETY MANAGEMENT SYSTEMS APPLIED TO THE LITHUANIAN FOOD SECTOR
}

\author{
Ausra Steponaviciene $^{1 *}$, Nijole Vasiliauskiene ${ }^{1}$, Dainius Steponavicius ${ }^{2}$, Edita Kurtkuviene ${ }^{1}$ \\ ${ }^{1}$ Catering Department, Faculty of Technologies, Kaunas University of Applied Science, Pramones Ave. 22, Kaunas, Lithuania, \\ e-mail: steponaviciene.ausra@gmail.com \\ ${ }^{2}$ Aleksandras Stulginskis University, Institute of Agricultural Engineering and Safety, Studentu 15A, Kaunas, Lithuania
}

\begin{abstract}
Food safety assurance is one of the most important and significant issues in the activity of the food sector. Product certification process according to various standards means the highest quality not only for the company but for the consumer as well. Company's executives are free to choose what a management system should be introduced in the organization. It must be effective and viable. International standards and modern quality management systems have been developed and currently are widely used to accomplish this task. In order to ensure the highest quality requirements in all food supply chain, companies often implement and integrate quality, environmental and food safety management. However, the company's executives faces many difficulties to select which of the management systems is superior and the most appropriate for certain company.

This paper analyses the requirements of the international standards towards the food safety and quality for the establishment of food quality and food safety management systems; similarities and differences between them, to evaluate the application of these systems, the main advantages and disadvantages. Implementation of the quality and safety management systems in Lithuanian food companies was analysed. At least one management system is certified at the 87 Lithuanian food companies. Of these, the management system according to the ISO 9001:2015 standard is certified at 48 companies, according to the ISO 22000:2005 - at 53 companies, and according to the requirements of the British Retail Consortium standard - at 31 companies. Even $45 \%$ of the companies have implemented and are certified by two or more mutually integrated management systems.
\end{abstract}

Keywords: food safety assurance, certification, quality management systems.

\section{Introduction}

Development in the international food trade introduced a new range of food safety and quality management standards. The company's decision to apply a certain management system according to various standard requirements affects the chance for the company to remain in the competitive market. The applied system has to be effective and viable. Its application in the company should provide top quality results. One way to achieve such results is system integration, when the company introduces a number of management systems (quality, food safety or environmental protection). When properly integrating separate management systems into the process, costs can be reduced by 30-40 percent when compared with the individual management systems. However, company management often has difficulties in assessing, which management system is superior and in what ways management systems are similar to each other and how they differ (Rezaei et al., 2011).

Many of the new safety concepts and quality parameters of the utmost importance are applied: Hazard Analysis and Critical Control Point (HACCP), total quality management, corporate certification to the international ISO (International Organization for Standardization) standards (Venskutonis, 2006).

As food safety is related to the appearance of potential food safety risk factors, risk management is necessary in every step of food processing. Food safety is assured by joint efforts of every party, participating in food processing. To avoid any risks, food businesses must be subject to good hygienic practices or the HACCP Hazard Analysis and Critical Control Points system. HACCP is applied in food companies according to the following criteria:

o hazard analysis;

o Critical Control Points (CCP) implementation to manage potential risks;

o setting critical limits for set Critical control points;

o establishing monitoring system for CCP's;

o establishing corrective actions;

o establishing food management system and inspection procedures;

o 'essential program' establishment to ensure the hygiene controls.

LST EN ISO 22000:2005 / AC: 2006 standard describes the requirements for HACCP criteria and additional requirements to ensure food safety (clear tracking system, management of potentially unsafe products and others) (Food safety..., 2006). According to LST EN ISO 22000:2005/AC:2006, BRC (British Retail Consortium) and IFS (International Food Standard) standards, food companies must carry out food safety risk analysis and establish management methods for the elimination of risk factors.

Food retail suppliers are subject to the IFS and BRC standards. The IFS is designed for the German, French and Italian retail trade associations (IFS, 2008) and the global standard for food safety BRC - British Retail Consortium (BRC, 2015). IFS and BRC standards are designed to ensure supplier compliance and secure retailers' ability to guarantee the safety and quality of marketed products. Today it is used worldwide as a business (trade or processing) system, enabling the production of safe food and the selection of reliable suppliers.

World practice shows that nowadays the quality management systems (Quality management..., 2015a; Quality management..., 2015b) are very popular in 
organizations, and most often they are introduced and developed, based on the total quality management concept and/or the ISO 9000 series of standards (Markevičiūtè, 2007). Practice of total quality management is rarely applied in Lithuanian companies. Total quality management and efficiency of the companies is widely analysed by Kaunas University of technology professor P. Vanagas (2004). Ruževičius (2006a) described the total quality management and integration of information management model. According to Markevičiūtè (2007), some researchers argue that the ISO 9000 series of standards, requirements and total quality management are incompatible, and the other authors believe that these systems complement each other and upon integration of these systems in a single organization, synergy effect can be achieved.

Organizations whose leadership is more interested in health and safety of their employees implement health and safety systems according to the requirements of international standard BS OHSAS 18001:2007 (Occupational health and safety assessment series is an internationally applied British standard for occupational health and safety management systems). This system applies to professional risks associated with normal operations and management of abnormal situations (Occupational health..., 2009).

Lithuanian and foreign author's scientific works (Melece, Romanova, 2007; Ruževičius et al., 2004; Savov, Kouzmanov, 2009) tend to describe and analyse quality (ISO 9001), environment (according to the ISO 14001 standard) and food safety (in accordance with ISO standard 22000) management systems, applied in food companies without conducting extensive research on these systems. Ruževičius (2006b) summarized an integrated quality and food safety management systems (according to ISO 9001 and ISO 22000 standards) implemented in one food company, stated that the complete analysis of this issue has not yet been done not only in Lithuanian, but also in the world's scientific literature. Therefore, it can be said that research in support of the use of integrated management systems, their synergy and positive changes in food sector has not been conducted yet.

The aim of the paper is to examine the development of management system implementation in Lithuanian food companies.

\section{Materials and Methods}

An analysis of differences and similarities between the most commonly implemented management systems was conducted using the data of years 2011, 2014 and 2015 published by the Lithuanian Standardisation Department concerning certified management systems as well as international management systems applicable standards (ISO 9001, ISO 22000, ISO 14001, IFS, BRC and OHSAS). In this article, the data cover all Lithuanian registered food companies, which have at least one management system. Processing of the results applied to the comparative analysis method
(Steponavičiené et al., 2011). In addition, management system integration opportunities in Lithuanian food sector were presented.

\section{Results and Discussion}

Responsibility for food safety rests with the company, which supplies a product to the market. The importance of successful food safety management increases depending to the company size, production amounts, food product, or it's part risks. Widespread method to achieve this goal is an independent certification according to the quality and food safety standards (ISO 9001, ISO 22000, BRC, IFS, etc.), when a certificate means that food safety assurance level of the company matches the standard.

Comparing 2015 to 2014 and 2011, the data showed that the number of certified food companies is growing every year (Fig. 1). Lithuania, under international management systems standards, in 2011, certified 70 food companies, in 2014 - 77 food companies, in 2015 - 87 food companies.

Out of all certified Lithuanian food companies, most companies (44 - in 2011 and 55 - in 2014) were certified according to ISO 9001:2008 standard and 48 - in 2015 were certified according to ISO 9001:2015 standard (Fig. 1). 26 companies (in 2011), 34 companies (in 2014), and 53 companies (in 2015) had a management system under ISO 22000:2005 standard requirements. Food safety according to the IFS standard was certified in 3 food companies (in 2011), 10 food establishments (in 2014) and 13 food establishments (in 2015), and according to the BRC standard requirements - 1 food establishments (in 2011), 28 food companies (in 2014), 31 food company (in 2015). Occupational health and safety standard (OHSAS) requirements in 2011 were applied in 5 and 2014 and 2015 - 9 Lithuanian food companies. The evaluation of the results over the years 2011-2015 show a significant trend of more and more management systems set according to the specific food sector created standards such as ISO 22000:2005, BRC and IFS.

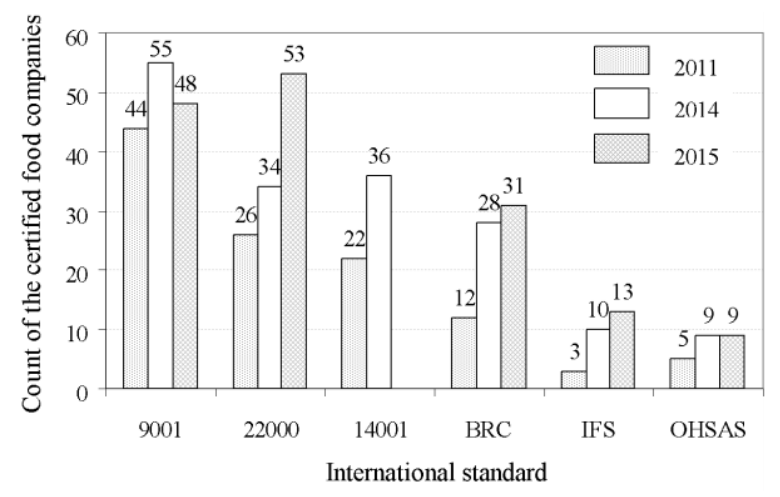

Figure 1. Implemented management systems at the Lithuanian food companies according to the international standards

Implementation and certification of each individual management system in a food company means additional expenses, therefore there is an opportunity to 
integrate separate management systems into each other. For example: food companies commonly imply quality and food safety management system integration in accordance to ISO 9001:2015 and ISO 22000:2005/AC:2006 standard requirements. Implementation and certification of each individual management system (quality, food safety) in company requires additional resources, so it is possible for separate systems to be integrated into each other, e.g., food companies often used in quality and food safety management system integration according to international standards (ISO 9001:2015 and ISO 22000:2005/AC:2006) requirements.

Differences and similarities between management systems (in accordance with international standards ISO 9001:2015, ISO 22000:2005, BRC and IFS requirements) used in quality and food safety assurance are shown in Table 1.

Table 1

Differences and similarities between quality and food safety management systems

\begin{tabular}{|c|c|c|}
\hline $\begin{array}{l}\text { Management } \\
\text { system }\end{array}$ & $\begin{array}{c}\text { General } \\
\text { requirements }\end{array}$ & $\begin{array}{c}\text { Specific } \\
\text { requirements }\end{array}$ \\
\hline \multirow{3}{*}{$\begin{array}{l}\text { Quality } \\
\text { management } \\
\text { system } \\
\text { (according to the } \\
\text { ISO 9001:2015) }\end{array}$} & Policy & $\begin{array}{l}\text { Planning of } \\
\text { product sale }\end{array}$ \\
\hline & Resource control & Projection \\
\hline & $\begin{array}{l}\text { Documentation } \\
\text { control }\end{array}$ & Risk management \\
\hline \multirow{6}{*}{$\begin{array}{l}\text { Food safety } \\
\text { management } \\
\text { system } \\
\text { (according to the } \\
\text { ISO 22000:2005), } \\
\text { BRC, IFS }\end{array}$} & $\begin{array}{l}\text { Nonconformity } \\
\text { control }\end{array}$ & $\begin{array}{l}\text { Planning of safe } \\
\text { product and its } \\
\text { realization }\end{array}$ \\
\hline & Planning & \\
\hline & $\begin{array}{c}\text { Resource } \\
\text { management }\end{array}$ & $\begin{array}{c}\text { establishment for } \\
\text { possible risk } \\
\text { control }\end{array}$ \\
\hline & & \\
\hline & & $\begin{array}{l}\text { Establishment of } \\
\text { CCP monitoring }\end{array}$ \\
\hline & $\begin{array}{l}\text { Continuous } \\
\text { improvement }\end{array}$ & $\begin{array}{c}\text { and management } \\
\text { systems }\end{array}$ \\
\hline
\end{tabular}

Out of all certified Lithuanian food companies, 39 companies (in 2011), 48 companies (in 2015) had implemented at least one management system in accordance with international standards, 23 companies (in 2011), 25 companies (in 2015) had implemented two integrated management systems in accordance with international standards (Fig. 2 and 3). A smaller number of companies had implemented three integrated management systems in accordance with international standards - 5 (in 2011), 10 companies (in 2015), while four integrated management systems in accordance with international standards were applied in 3 (in 2011) and in 4 companies (in 2015).

In most cases companies implement integrated management systems certified according to ISO 9001:2015 and the ISO 22000:2005, 16 companies (in 2015) a little less companies according to the BRC and the ISO 22000:2005 -
3 companies or by BRC and IFS - 4 companies. 10 companies had integrated 3 management systems. Most often integrated systems are: ISO 22000:2005, ISO 9001:2015, OHSAS and BRC. In conclusion, it can be said that in order to save resources, companies more and more often integrate different management systems taking their similarities into consideration.

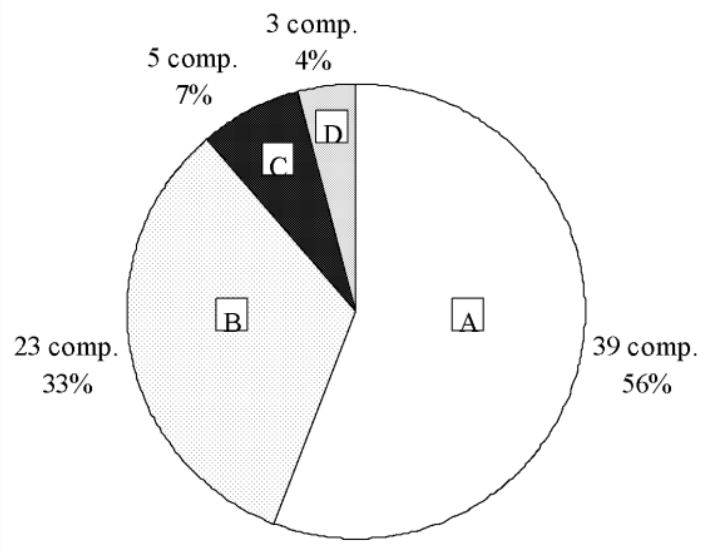

Figure 2. Integration of management systems at the Lithuanian companies in 2011

A - companies with one certified management system; B - with two certified management systems; C - with three certified management systems; D - with four certified management systems

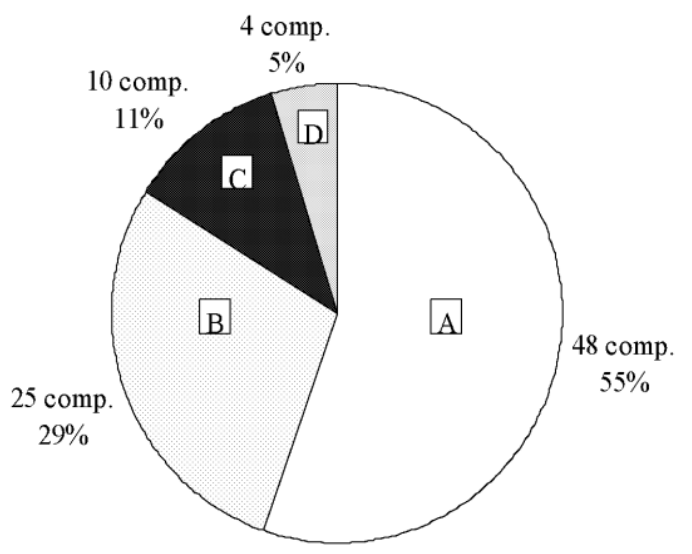

Figure 3. Integration of management systems at the Lithuanian companies in 2015

A - companies with one certified management system; B - with two certified management systems; C - with three certified management systems; D - with four and more certified management systems

Organizations that have a management system implemented in accordance to the standard requirements are considered as reputable and trustworthy partners, who do not aim for short-term goals, but seek long-term goals and quality. After implementing management system, employees clearly understand company policies, goals, their duties and responsibilities. Management systems make the clients put more trust in the company (Vanagas, 2004). Implementation of every separate management system costs resources; therefore it is recommended to integrate different management systems (Ruževičius, 2006b). As opposed to quality 
management, environment protection, work safety and healthcare companies, food safety management systems (BRC; IFS; ISO 22000) are implemented only in food companies. Lithuanian food companies successfully apply not only food safety management systems, but environment protection, work safety and healthcare systems.

\section{Conclusions}

The company's decision to apply a certain management system according to various standard requirements affects the chance for the company to remain in the competitive market. To achieve the best results, while reducing costs and non-compliances, a constant development of management systems is required.

Comparison of data from 2011, 2014 and 2015, it was concluded that the number of certified food companies is growing. Most Lithuanian food companies are certified in accordance to ISO 22000:2005, second place -48 in accordance to ISO 9001:2015 quality management standard, third place -31 in accordance to global standard for food safety (BRC).

In 2015 out of 87 food companies in Lithuania 48 companies were certified according to at least one management system, 25 companies were certified with at least two integrated management systems, 14 companies were certified with three or more integrated management systems.

Most commonly integrated management systems are certified in accordance to ISO 9001:2015, ISO 22000:2005, occupational health and safety standard (OHSAS) or in accordance to BRC.

\section{References}

1. BRC. Global standard for food safety (2015) British Retail Consortium. London, Issue 7.

2. Food safety management systems. Requirements (2006) LST EN ISO 22000:2005/AC:2006 Lithuanian Standardization Department. Vilnius.
3. IFS. International Food Standard (2008). HDE Trade Services GmbH. Germany, Version 5.

4. Markevičiūtė L. (2007) Documents - an inherent element of the quality management system. Informacijos mokslai. Vol. 40, p. 73-80.

5. Melece L., Romanova D. (2007) Issues of sustainable food production in Latvia. Economics and Rural Development, Vol. 3(2), p.16-21.

6. Occupational health and safety management systems. Requirements (2009) BS OHSAS 18001:2007. Lithuanian Standardization Department. Vilnius.

7. Quality management systems. Fundamentals and vocabulary (2015a) LST EN ISO 9000:2015. Lithuanian Standardization Department. Vilnius.

8. Quality management systems. Requirements (2015b) LST EN ISO 9001:2015. Lithuanian Standardization Department. Vilnius.

9. Rezaei A. R., Çelik T., Baalousha Y. (2011) Performance measurement in a quality management system. Scientia Iranica, Vol. 18(3), p. 742-752.

10. Ruževičius J. (2006a) Integration of total quality management and knowledge management. Informacijos mokslai, Vol. 37, p. 30-38. (in Lithuanian)

11. Ruževičius J. (2006b) The study of the assumptions of development quality and product's safety integrated system. Engineering Economics, Vol. 46(1), p. 69-73.

12. Ruževičius J. Adomaitienè R., Sirvydaitė J. (2004). Motivation and efficiency of quality management systems implementation: a study of Lithuanian organizations. Total quality management and business excellence, Vol. 15(2), p. $173-189$.

13. Savov A. V, Kouzmanov G. B. (2009) Food quality and safety standards at a glance. Biotechnology \& Biotechnological Equipment, Vol. 23(4), p. 1462-1468.

14. Steponavičienè A., Kemzūraitė A., Stankevičienè M., Kraujutiene I. (2011) Management systems applied to the Lithuanian food sector. In: The 17th International Scientific-practice conference "Human and Nature Safety 2011"; Conference Proceedings, Vol. 1, Lithuania, Kaunas-Akademija, p. 119-122.

15. Vanagas P. (2004) Total quality management. Kaunas: Technologija. $426 \mathrm{p}$.

16. Venskutonis P. (2006) Review of scientific research in European Union: for food industry, Vol. 3, p. 927-943. 